\title{
Grand challenges in conservation research
}

\author{
Ralf C. Buckley * \\ School of Environment, Griffith University, Gold Coast, QLD, Australia
}

Keywords: taxonomy, genetic, impact, ecology, social, economic, finance, policy

\section{INTRODUCTION}

One of the privileges and responsibilities accorded to Specialty Chief Editors in the Frontiers journals, at the commencement of new specialty sections, is to provide an overview of potential research directions for the specialization in the form of a challenge statement. There is, however, a tight restriction on this prerogative: specifically, a limit of 2000 words. For the very practical and urgent discipline of conservation, this poses a challenge in itself. Should one focus on what is most significant, most urgent, or most innovative? As a compromise, this contribution follows a two-part approach.

The first part provides a brief review of the global context for conservation, a reminder of the human social context in which conservation operates. The second part attempts to identify some priorities in the various research disciplines that contribute to conservation knowledge. Most researchers have specialist expertise. A list of priorities in, say, economics is of little use to a

OPEN ACCESS

Edited by:

Matt W. Hayward,

Bangor University, UK

Reviewed by:

Stephen Thomas Garnett,

Charles Darwin University, Australia

Paul Cross,

Bangor University, UK

*Correspondence:

Ralf C. Buckley

r.buckley@griffith.edu.au;

ralf.c.buckley@gmail.com

Specialty section:

This article was submitted to

Conservation,

a section of the journal

Frontiers in Ecology and Evolution

Received: 04 June 2015

Accepted: 26 October 2015

Published: 05 November 2015

Citation:

Buckley RC (2015) Grand challenges

in conservation research.

Front. Ecol. Evol. 3:128.

doi: 10.3389/fevo.2015.00128 geneticist, or vice versa. Indeed, even within any one discipline-taxonomy, say-most individual researchers amass expertise only for particular taxa. There is little cross-over between bird, frog, insect, and fish taxonomy. However, students entering any research discipline still have that choice. Perhaps this outline may influence how they make it.

\section{CONSERVATION CONTEXT}

The grand challenge for conservation of biodiversity is simple to state, but complex to solve. The Earth supports over seven billion people, with increasing human population, resource consumption, and environmental footprint. Many other species are up to nine orders of magnitude fewer in number, threatened by habitat degradation, hunting and harvesting, pathogens and pollution. There are no longer any safe havens for any species, anywhere. Conservation of biological diversity is thus simultaneously important, urgent, insufficient, underfunded, controversial, and politicized (Butchart et al., 2010; Hoffmann et al., 2010; Pereira et al., 2010; Barnosky et al., 2011, 2012; Saterberg et al., 2013; Waldron et al., 2013; Pimm et al., 2014; Ripple et al., 2014; Tittensor et al., 2014; Woinarski et al., 2015).

Reducing human impacts on biodiversity is technically possible. Individual humans have finite lifespans, and can choose fewer children and lower consumption. Evolution, however, has produced pressures to amass wealth and produce offspring. The probability of billions of people jointly making independent choices contrary to these pressures is small. In practice, few nations have achieved zero or negative population growth, or deliberate reduction in resource consumption or even GDP. Therefore, the only practical option available for conservation, at least by deliberate human choice, is to construct social machines using politics, laws, finance and communications. Many social machines already exist: armies, industries, governments, health and welfare systems, religions, universities. Some are weak, others powerful. At present, conservation is a weak social 
machine. Powerful political and commercial organizations oppose it openly and directly, and billions of individuals oppose it unknowingly and indirectly, simply through modern consumerist lifestyles.

One major challenge in analysing conservation, therefore, is to recognize that it involves a political contest, conservation advocates against conservation opponents. Conservation competes with many other more powerful and pressing human demands. Of course, science and advocacy are very different and distinct activities. Conservation researchers are not necessarily conservation advocates, and if they are, their advocacy is a different process from their research. In politically controversial fields, however, including conservation, research results are regularly used by advocates. Whether intentionally or inadvertently, conservation researchers operate within a highly contested political arena.

In addition, this contest has no fixed rules. Seeking more resources for conservation, for example, yields larger-scale consequences than reallocation of existing resources. The rules of human social systems can indeed change markedly over time. Historical examples include outlawing slavery, colonial independence, and female suffrage. These changes were perceived politically as public goods. There is thus no fundamental social reason why conservation cannot become recognized as a global priority. To do so, however, its advocates must overcome its opponents, in the same way that advocates for global action against climate change must overcome those who deny it. This is indeed a grand challenge.

And in the same way that climate scientists are embroiled in political contests over climate change, conservation scientists are entangled in political contests between conservation advocates and opponents.

\section{RESEARCH CHALLENGES}

Practical conservation is a social-ecological system involving government agencies, private enterprises, community organizations, and non-government organizations, as well as species and ecosystems (Karanth and deFries, 2010; Perrings et al., 2011; Balmford, 2012; McCarthy et al., 2012; Buckley and Pegas, 2014; Ferraro and Hanauer, 2014; Hauser et al., 2014; Pouzols et al., 2014; Schwitzer et al., 2014).

Immediate threats to conservation of biodiversity are wellknown. They include: loss and degradation of habitat, climate change, chemical and biochemical pollution, logging and poaching, invasive species, disease, loss of plant pollinators, and many more. A number of new and additional concerns were listed recently by Sutherland et al. (2015).

Public protected areas, albeit imperfect, are still the single most effective conservation tool (Di Minin, 2013; Coetzee et al., 2014; Le Saout et al., 2014; Pouzols et al., 2014; Pressey et al., 2014; Sloan et al., 2014; Tranquilli et al., 2014). Approaches aiming to connect public protected areas through other land tenures, and provide resources through other stakeholders, can also provide a valuable complement to publicly funded parks systems. Conservation research priorities must therefore consider both the establishment, expansion and management of public parks systems, and the improvement of conservation management outside these systems.

Conservation is cross-disciplinary, but most research is discipline-based. Here, therefore, I propose research challenges in various relevant fields. Research disciplines relevant to the ecological components of conservation include taxonomy, genetics, distributions, life histories, population ecology, and interspecies interactions. Research relevant to the social components includes human psychology and behavior, politics, law and economics.

Taxonomic research is increasingly urgent, as more and more species become extinct before they have even been described (Costello et al., 2013; Tedesco et al., 2014). What species are yet to be discovered in regions of the world that are difficult for scientists to reach, but nonetheless subject to anthropogenic impacts? Examples include the deep oceans (Armbrust and Palumbi, 2015), and forests in many parts of the tropics and subtropics, where civil wars, illegal logging and disease outbreaks restrict access and simultaneously damage ecosystems.

Reductions in population sizes and ranges of threatened species also generate losses in genetic diversity (Allendorf et al., 2010; Padial et al., 2010; Segelbacher et al., 2010; Leffler et al., 2012). Small and geographically isolated remnant populations may contain greater genetic diversity than more extensive populations elsewhere. For threatened species where individuals migrate from source to sink areas, loss of genetic diversity in source areas will also affect sink areas. Genetic variation between sister species, subspecies and geographic variants is critical in determining joint conservation strategies. The scarcity of data on geographic patterns in genetic diversity for many threatened species is of particular concern as some conservation analysts adopt approaches based on triage.

Ecological interactions between species are constantly being changed by anthropogenic impacts at local and global scales, with potentially severe conservation consequences. This includes both large-scale patterns such as geographic assemblages and trophic webs, and finer-scale interactions involved in the life cycles of individual species. Anthropogenically-modified interspecies interactions have been analyzed in fields such as recreation ecology, restoration ecology, and climate change ecology (Burrows et al., 2014; Garcia et al., 2014), but less so for conservation ecology more broadly.

Many species and ecosystems are threatened jointly by large-scale impacts associated with human population growth, industrialization, and pollution (Hallmann et al., 2014) and local-scale impacts from development projects and land-use changes (Brashares et al., 2014). One conservation response to climate change is to increase resilience of protected areas and threatened species, by reducing other anthropogenic impacts. In practice, however, multiple impacts all increase simultaneously. Most countries operate project-scale development impact assessment systems (Morgan, 2012; Wathern, 2013; Smith, 2014), but these are rarely linked to policy and legislation at national scale, or to intergovernmental agreements at international scale (Fundingsland Tetlow and Hanusch, 2012). 
Conservation operates within a social context, and the social contexts may differ greatly between places. Where parks and conservation have local support, protecting them from damage and degradation is much easier and more effective than where they do not (Buckley and Pabla, 2012). This includes issues of illegal access, harvesting and poaching, and applies in developed as well as developing nations. Understanding and influencing the attitudes of different communities and stakeholders toward conservation is therefore a key component of conservation efforts.

The effectiveness of either public or private conservation reserves depends on broader-scale political and social stability, cultural acceptability, and the rule of law and order without corruption or violence. Many policy instruments have been trialed to improve conservation on various different land tenures. Examples include easements, incentives, offset, and buyback programs, ecosystems services payments (Wunder, 2014; CavenderBares et al., 2015), and business approaches such as bio-prospecting and ecotourism. One research challenge is to evaluate which mechanisms are most effective under what circumstances.

Conservation needs funds: to acquire and manage reserves, provide conservation incentives outside reserves, combat threats and pressures on protected areas and individual species, and support breeding and translocation programmes (Balmford et al., 2002; McCarthy et al., 2012). Governments underfund conservation because its political benefits are diffuse, delayed, and undervalued. Public parks charge visitor fees, typically a tenth of total revenue in developed nations, but up to four fifths in some developing nations. Many private and communal conservancies are funded through commercial tourism, but opportunities differ between sites and can change suddenly. The same applies for sale of ecosystem services such as water supply or carbon sequestration. Some parks sell sponsorships, branding rights and merchandise. All of these approaches merit research on applicable

\section{REFERENCES}

Allendorf, F. W., Hohenlohe, P. A., and Luikart, G. (2010). Genomics and the future of conservation genetics. Nat. Rev. Genetics 11, 697-709. doi: $10.1038 / \mathrm{nrg} 2844$

Armbrust, E. V., and Palumbi, S. R. (2015). Uncovering hidden worlds of ocean biodiversity. Science 348, 865-867. doi: 10.1126/science.aaa7378

Balmford, A. (2012). Wild Hope: On the Front Lines of Conservation Success. Chicago, IL: University of Chicago Press.

Balmford, A., Bruner, A., Cooper, P., Costanza, R., Farber, S., Green, R. E., et al. (2002). Economic reasons for conserving wild nature. Science 297, 950-953. doi: 10.1126/science.1073947

Barnosky, A. D., Hadly, E. A., Bascompte, J., Berlow, E. L., Brown, J. H., Fortelius, M., et al. (2012). Approaching a state shift in Earth's biosphere. Nature 486, 52-58. doi: 10.1038/nature11018

Barnosky, A. D., Matzke, N., Tomiya, S., Wogan, G. O. U., Swartz, B., Quental, T. B., et al. (2011). Has the Earth's sixth mass extinction already arrived? Nature 471, 51-57. doi: 10.1038/nature09678

Brashares, J. S., Abrahms, B., Fiorella, K. J., Golden, C. D., Hojnowski, C. E., Marsh, R. A., et al. (2014). Wildlife decline and social conflict: policies aimed circumstances, social support, effective design and future potential.

\section{CONCLUSIONS}

Covering taxonomy, genetics, ecological interaction, impact assessment, social behavior, policy, and finance, the research priorities presented above no doubt reflect my own personal experiences. These include: commercial industry and government advisory bodies as well as academia; practice as well as research; and exposure to politics, law, economics, and social structures, as well as biology and ecology, in different parts of the world. It is a broad canvas at best, and I look forward to detailed blueprints from Editors and contributors.

Of all the multitudinous impacts of humankind on the rest of the planet, perhaps three are most severe and most difficult to reverse: species extinctions, large-scale ocean pollution, and climate change. Of these three, pollution and climate change are perhaps still within the range where natural recovery might be possible if continuing human impacts were halted, even though any such halt is highly improbable under continuing human population growth. Species extinctions, however, do not reverse themselves. Even though humans may perhaps, with great effort and investment, be able to reconstitute particular individual species from preserved remnant materials, this is not a realistic option for most extinctions.

Conservation of biological diversity, difficult and disheartening though it may seem at times, should surely be one of humankind's highest priorities. We may not always succeed, but everything we can achieve is important. My aim here is to show that in every ecological research discipline, there are research questions at all scales and levels which can indeed contribute to the practical grand challenges of conservation, as outlined in the first section of this contribution. We hope and trust that the Conservation Specialty Section of Frontiers in Ecology and Evolution will attract many such publications! at reducing wildlife-related conflict must address the underlying causes. Science 345, 376-378. doi: 10.1126/science.1256734

Buckley, R. C., and Pabla, H. S. (2012). Tourism ban won't help Indian tigers. Nature 489, 33. doi: 10.1038/489033b

Buckley, R. C., and Pegas, F. de V. (2014). Conserving Brazil's Atlantic forests. Science 246, 1193. doi: 10.1126/science.346.6214.1193-a

Burrows, M. T., Schoeman, D. S., Richardson, A. J., Molinos, J. G., Hoffmann, A., Buckley, L. B., et al. (2014). Geographical limits to species-range shifts are suggested by climate velocity. Nature 507, 492-495. doi: 10.1038/nature12976

Butchart, S. H. M., Walpole, M., Collen, B., van Strien, A., Scharlemann, J. P. W., Almond, R. E. A., et al. (2010). Global biodiversity: indicators of recent declines. Science 328, 1164-1168. doi: 10.1126/science.1187512

Cavender-Bares, J., Polasky, S., King, E., and Balvanera, P. (2015). A sustainability framework for assessing trade-offs in ecosystem services. Ecol. Soc. 20:17. doi: 10.5751/es-06917-200117

Coetzee, B. W., Gaston, K. J., and Chown, S. L. (2014). Local scale comparisons of biodiversity as a test for global protected area ecological performance: a meta-analysis. PLoS ONE 9:e105824. doi: 10.1371/journal.pone.0105824

Costello, M. J., May, R. M., and Stork, N. E. (2013). Can we name the Earth's species before they go extinct? Science 339, 413-416. doi: 10.1126/science.1230318 
Di Minin, E. (2013). Creating larger and better connected protected areas enhances the persistence of big game species in the Maputaland-PondolandAlbany biodiversity hotspot. PLOS ONE 8:e71788. doi: 10.1371/journal.pone. 0071788

Ferraro, P. J., and Hanauer, M. H. (2014).Quantifying causal mechanisms to determine how protected areas affect poverty through changes in ecosystem services and infrastructure. Proc. Natl. Acad. Sci. U.S.A. 111, 4332-4337. doi: $10.1073 /$ pnas.1307712111

Fundingsland Tetlow, M., and Hanusch, M. (2012). Strategic environmental assessment: the state of the art. Impact Assess. Project Apprais. 30, 15-24. doi: $10.1080 / 14615517.2012 .666400$

Garcia, R. A., Cabeza, M., Rahbek, C., and Araújo, M. B. (2014). Multiple dimensions of climate change and their implications for biodiversity. Science 344:1247579. doi: 10.1126/science. 1247579

Hallmann, C. A., Foppen, R. P., van Turnhout, C. A., de Kroon, H., and Jongejans, E. (2014). Declines in insectivorous birds are associated with high neonicotinoid concentrations. Nature 511, 341-343. doi: 10.1038/nature13531

Hauser, O. P., Rand, D. G., Peysakhovich, A., and Nowak, M. A. (2014). Cooperating with the future. Nature 511, 220-223. doi: 10.1038/nature13530

Hoffmann, M., Hilton-Taylor, C., Angulo, A., Böhm, M., Brooks, T. M., Butchart, S. H. M., et al. (2010). The impact of conservation on the status of the world's vertebrates. Science 330, 1503-1509. doi: 10.1126/science.1194442

Karanth, K. K., and deFries, R. (2010).Conservation and management in humandominated landscapes: case studies from India. Biol. Cons. 143, 2865-2869. doi: 10.1016/j.biocon.2010.05.002

Leffler, E. M., Bullaughey, K., Matute, D. R., Meyer, W. K., Ségurel, L., Venkat, A., et al. (2012). Revisiting an old riddle: what determines genetic diversity levels within species. PLoS Biol. 10:e1001388. doi: 10.1371/journal.pbio.1001388

Le Saout, S., Hoffmann, M., Shi, Y., Hughes, A., Bernard, C., Brooks, T. M., et al. (2014). Protected areas and effective biodiversity conservation. Science 342, 803-805. doi: 10.1126/science. 1239268

McCarthy, D. P., Donald, P. F., Scharlemann, J. P., Buchanan, G. M., Balmford, A., Green, J. M., et al. (2012). Financial costs of meeting global biodiversity targets: current spending and unmet needs. Science 338, 946-949. doi: $10.1126 /$ science. 1229803

Morgan, R. K. (2012). Environmental impact assessment: the state of the art. Impact Assess. Project Apprais. 30, 5-14. doi: 10.1080/14615517.2012.661557

Padial, J. M., Miralles, A., De la Riva, I., and Vences, M. (2010). Review: the integrative future of taxonomy. Front. Zool. 7:16. doi: 10.1186/1742-9994-7-16

Pereira, H. M., Leadley, P. W., Proença, V., Alkemade, R., Scharlemann, J. P. W., Fernandez-Manjarrés, J. F., et al. (2010). Scenarios for global biodiversity in the $21^{\text {st }}$ century. Science 330, 1496-1501. doi: 10.1126/science.1196624

Perrings, C., Duraiappah, A., Larigauderie, A., and Mooney, H. (2011). The biodiversity and ecosystem services science-policy interface. Science 331, 1139-1140. doi: 10.1126/science. 1202400

Pimm, S. L., Jenkins, C. N., Abell, R., Brooks, T. M., Gittleman, J. L., Joppa, L. N., et al. (2014). The biodiversity of species and their rates of extinction, distribution and protection. Science 334:1246752. doi: 10.1126/science. 1246752

Pouzols, F. M., Toivonen, T., Di Minin, E., Kukkala, A. S., Kullberg, P., Kuusterä, J., et al. (2014). Global protected area expansion is compromised by projected land-use and parochialism. Nature 516, 383-386. doi: 10.1038/nature14032

Pressey, B., McCauley, D. J., Morgan, L., Possingham, H., White, L., Darling, E., et al. (2014). A to-do list for the world's parks. Nature 515, 28-31. doi: $10.1038 / 515028 \mathrm{a}$
Ripple, W. J., Estes, J. A., Beschta, R. L., Wilmers, C. C., Ritchie, E. G., Hebblewhite M., et al. (2014). Status and ecological effects of the world's largest carnivores. Science 343:1241484. doi: 10.1126/science.1241484

Säterberg, T., Sellman, S., and Ebenman, B. (2013). High frequency of functional extinctions in ecological networks. Nature 499, 468-470. doi: 10.1038 /nature12277

Schwitzer, C., Mittermeier, R. A., Johnson, S. E., Donati, G., Irwin, M., Peacock, H., et al. (2014). Averting lemur extinctions amid Madagascar's political crisis. Science 343, 842-843. doi: 10.1126/science. 1245783

Segelbacher, G., Cushman, S. A., Epperson, B. K., Fortin, M. J., Francois, O., Hardy, O. J., et al. (2010). Applications of landscape genetics in conservation biology: concepts and challenges. Conserv. Genetics 11, 375-385. doi: 10.1007/s10592009-0044-5

Sloan, S., Jenkins, C. N., Joppa, L. N., Gaveau, D. L., and Laurance, W. F. (2014). Remaining natural vegetation in the global biodiversity hotspots. Biol. Cons. 177, 12-24. doi: 10.1016/j.biocon.2014.05.027

Smith, L. G. (2014). Impact Assessment and Sustainable Resource Management. London: Routledge.

Sutherland, W. J., Clout, M., Depledge, M., Dicks, L. V., Dinsdale, J., Entwistle, A. C., et al. (2015). A horizon scan of global conservation issues for 2015. Trends Ecol. Evol. 30, 17-24. doi: 10.1016/j.tree.2014.11.002

Tedesco, P. A., Bigorne, R., Bogan, A. E., Giam, X., Jezequel, C., and Hugueny, B. (2014). Estimating how many undescribed species have gone extinct. Cons. Biol. 28, 1360-1370. doi: 10.1111/cobi.12285

Tittensor, D. P., Walpole, M., Hill, S. L. L., Boyce, D. G., Britten, G. L., Burgess, N. D., et al. (2014). A mid-term analysis of progress towards international biodiversity targets. Science 346, 241-244. doi: 10.1126/science. 1257484

Tranquilli, S., Abedi-Lartey, M., Abernethy, K., Amsini, F., Asamoah, A., Balangtaa, C., et al. (2014). Protected areas in tropical Africa: assessing threats and conservation activities. PLOS ONE 9:e114154. doi: 10.1371/journal.pone.0114154

Waldron, A., Mooers, A. O., Miller, D. C., Nibbelink, N., Redding, D., Kuhn, T. S., et al. (2013). Targeting global conservation funding to limit immediate biodiversity declines. Proc. Natl. Acad. Sci. U.S.A. 110, 12144-12148. doi: 10.1073/pnas. 1221370110

Wathern, P. (2013). Environmental Impact Assessment: Theory and Practice. London: Routledge.

Woinarski, J. C., Burbidge, A. A., and Harrison, P. L. (2015). Ongoing unraveling of a continental fauna: decline and extinction of Australian mammals since European settlement. Proc. Natl. Acad. Sci. U.S.A. 112, 4531-4540. doi: $10.1073 /$ pnas. 1417301112

Wunder, F. (2014). Revisiting the concept of payments for environmental services. Ecol. Econ. 117, 234-243. doi: 10.1016/j.ecolecon.2014.08.016

Conflict of Interest Statement: The author declares that the research was conducted in the absence of any commercial or financial relationships that could be construed as a potential conflict of interest.

Copyright (C) 2015 Buckley. This is an open-access article distributed under the terms of the Creative Commons Attribution License (CC BY). The use, distribution or reproduction in other forums is permitted, provided the original author(s) or licensor are credited and that the original publication in this journal is cited, in accordance with accepted academic practice. No use, distribution or reproduction is permitted which does not comply with these terms. 